\title{
The Ethical Teacher in a High-Stakes Testing Environment
}

\author{
Jacqueline Arroyo-Romano \\ Texas A\&M International University \\ 5201 University Boulevard, Laredo, Texas 78041, United States \\ Tel: 956-326-2681Ｅ-mail: Jacqueline.romano@tamiu.edu \\ Stephen Benigno (corresponding) \\ Texas A\&M International University \\ 5201 University Boulevard, Laredo, Texas 78041, United States \\ Tel: 956-326-2681_E-mail: sbenigno@tamiu.edu
}

\begin{abstract}
Received: Feb. 3, 2016 Accepted: April 19, 2016 Published: May 1, 2016
doi:10.5296/jse.v6i2.9218 URL: http://dx.doi.org/10.5296/jse.v6i2.9218
\end{abstract}

\begin{abstract}
Increasing accountability expectations are causing teachers to rectify their responsibilities, to themselves, to their students and to the school administrations in which they work. Teachers have been torn between the responsibility to provide a quality education that reflects their knowledge and their training in their content area and to prepare their students for mandated assessments. State and District mandated assessments can have an impact on the delivery and the content of the curriculum in the classroom. These assessments can be the impetus for teachers to make specific decisions regarding the focus of their instruction and the delivery of their content. Teachers often feel obligated to emphasize the testing information at the expense of the specific curricula content. This adjustment in their curriculum can create an ethical dilemma for the teacher with regard to the emphasis of their instruction and the delivery of their instruction.

Discussed in the manuscript are the perceptions of two teachers regarding curriculum planning and the implementation of the curriculum. The relationship between teacher perception, ethical concepts and the implementation of instruction in the high stakes testing environment were explored in the study. The results of the study indicated that the teachers in the study felt obligated to provide a quality education for their students. However, the results
\end{abstract}




\section{Macrothink}

Journal of Studies in Education

ISSN 2162-6952 2016, Vol. 6, No. 2

also indicated that the pressures of the mandated assessment did have an effect on the delivery and preparation of their instruction. This decision to compromise created an ethical dilemma for the teachers in the study.

Keywords: value, ethics, assessment, mandates, dilemma 


\section{Introduction}

Most teachers enter the profession with a desire to make a contribution or make a difference in the lives of other people. Teachers are educated through a pedagogical process that has been developed to prepare students for the profession. Imbedded into the pedagogical process is an emphasis on values, ethical behavior and competency. Teachers most often approach their craft with an understanding of their responsibilities with regard to the delivery of the curriculum, the adherence to standards and the ethical responsibilities of the profession. Through their experiences with students, administrators, parents and other teachers, the teacher develops their own values, ethics and a vision of what and who they represent. Without the development and maintenance of a clear purpose and clarification of their values, it is difficult for them to assume and maintain the instructional leadership position in the classroom. "Too often what we have been doing is using these tests to punish students or to, in some cases, punish schools". "One thing I never want to see happen is schools that are just teaching to the test". "All you're learning about is how to fill out a little bubble on an exam and little tricks that you need to do in order to take a test and that's not going to make education interesting"( Barrack Obama, Town Hall, 2015). This public rhetoric can intensify the dichotomous relationship between the expectations of the government entities and the values and ethics of the teacher. If the president of the United States does not support the mandated assessment program, how does that affect the values and ethics of the classroom teacher?

\section{Literature Review}

Over the years, legislators, advocacy groups, think tanks, and policy makers have ascribed to educational policies that influence the perception of the public indicating that public school education, in particular, the teachers are unable to provide effective instruction to students (Craig, 2004; Craig, 2008; Cross, 2004). For years, influential politicians have taken advantage of educational reports or news in the media in order to influence the course of educational systems. An influential document that appealed the attention of the Nation's top leaders was "A Nation at Risk" (1983) report. This controversial report stimulated a number of debates concerning the validity of the data presented (EPERC, 2004); however, the recommendations initiated the movement toward the establishment of more stringent standards and higher expectations for students in $\mathrm{K}-16$." $[\mathrm{W}] \mathbf{e}$ recommend adopt more rigorous and measurable standards, and higher expectations, for academic performance and student conduct, . . . help students do their best educationally with challenging materials" ( $\mathrm{p}$. 17 ). A Nation at Risk ${ }^{1}$ (1983) set the tone for higher accountability systems to help improve an inefficient educational system that was "incoherent, outdated, [it was a] patchwork quilt of classroom learning led to an increasing number of student who were subjected to a "cafeteria-style curriculum" that diluted the course material and allowed them to advance through their schooling with a minimal effort"' (Graham ${ }^{2}, 2013$, paragraph 7). The aftermath of this report resulted in the beginning of the academic standards-based movement.

${ }^{1}$ http://www2.ed.gov/pubs/NatAtRisk/recomm.html 
In the following two decades, new educational reforms and policies were implemented to establish a stricter accountability system. It was determined that assessments would be created to gage the success of the initiatives. As these initiatives were taking effect, the demographic, political, cultural, economic and social aspects of the country were undergoing a transformation. Immigration, and the effects of second language instruction started to take a toll on the instructional process. Teaching was becoming more difficult and the challenges associated with curriculum development, instructional design, differentiated instruction and culturally sensitive instruction were adding complexity to an already tenuous profession.

The No Child Left Behind Act set higher accountability standards and higher academic expectations for all public K-12 schools. All students were held accountable for participating in the mandated assessment programs. States were mandated to create assessments that would accurately assess student progress. Teachers were required to be "highly qualified" and schools had to prove to be effective or allow for students and parents to choose what schools to attend (Department of Education, P.L.107-110). This was the first time that the federal government had intervened on issues of education at a deeper level and a system of rewards or sanctions took place for making or not making adequate yearly progress (AYP). The sanctions for not making AYP affected states, districts, schools, administrators, students and parents. These elements made many schools districts and their teachers change their practices (Lee \& Orfield, 2006). The expansion of federal power over the public school has reached deeper than ever before into teacher's classrooms (Cochrna-Smith \& Lytle, 2006, Sunderman, et al., 2004).

High stakes testing "directly and powerfully influences how teachers teach and students learn" (Madaus, 1988, p. 30). Studies have focused on teacher perceptions with regard to the assessments and their effect on instruction in the classroom. A body of research (Au, 2011; Cochran-Smith \& Lytle, 2006; Darling-Hammond, 2003; Valenzuela, 2005) noted that many teachers have become disenchanted with the effects of the assessments and that this disenchantment has affected their personal and professional careers. Many teachers have begun to question their ability to provide appropriate curriculum and instruction. Additionally teachers believe that they have an ethical responsibility to meet the instructional needs of their students they become demoralized and disappointed in their profession (Santoro, 2011). As a consequence of accountability pressure, many teachers are leaving the profession as teaching and schools have become factory- like structures that reduce teachers and students to numbers ( $\mathrm{Au}, 2011)$. The emphasis on the mandated assessments and the preparation for those assessments as required teachers to intrinsically evaluate their ethics and values as they relate to their responsibilities within the profession.

Pedagogical practice has changed in some schools as a result of the NCLB legislation. According to (Yeh, 2005), some teachers feel more accountable for improving the quality of the curriculum and instruction by integrating the test preparation practices into the existing curriculum. Some teachers perceive that high-stakes testing is a positive when test-score results were used to self- evaluate their teaching and to inform them on how students were doing (Bustos-Flores and Clark, 2003). Others expanded their curriculum and engaged in student-centered pedagogies, resulting in an increase in their students' test scores (Au, 2007; 
Cimbricz, 2002). Many studies report that high-stakes testing affects teachers' practice negatively in different ways as high-stakes testing takes time away from sound pedagogical practices and limit the use of a variety of student-centered pedagogical practices (Hinde, 2003; Menken, 2006; Murillo \& Flores, 2002; Pedulla, et al., 2003; Russell \& Abrams, 2004).

The major complaint about high-stakes testing is the limitations and narrowing of curricular content focusing on basic skills found only in the test material, reducing instruction of content knowledge (Shepart \& Dugherty, 1991; Hinde, 2003). Another area affected is the perception of reduction in creativity. Some teachers and students abandoned good teaching practices resulting in the weakening of creative and higher order thinking skills (Cunningham \& Sanzo, 2002; Lewis, 2009). Studies in the most affected environments are urban school settings with large numbers of minorities and students from low socioeconomic status (Herman \& Golan, 1991; Pedulla, et al., 2003; Sunderman, Tracey, Kim, \& Orfield, 2004; Kozol, 2005; Watanabe, 2007). According to Boardman and Woodruff, (2004) high stakes testing affected the implementation, fidelity and maintenance of new teaching methods. The assessment mandates can restrict teachers from creating engaging lessons. Time constraints and content expectations related to the assessments can require teachers to narrow the expectations of their curriculum. This narrowing of the curriculum and the creative limitations of instructional design has caused distress and frustration in many teachers.

\section{Virtue Ethics}

The ethical teacher looks at the teacher's process of reflection and decision-making for practice through the lens of the virtue ethics (Campbell, 2003), the ethic of care (Noddings, 1984), and the ethic of justice (Freire, 1998a, 2001, 2004). A teacher's ethical knowledge is determined by the individual's understanding and acceptance of the demands of their profession as they apply to their daily practice. Campbell believes that some teachers carry out their duties without being fully aware of the moral and ethical implications of their actions and decisions because their ethical dispositions are deeply embedded in their habits, feelings, and inclinations (character). Virtue ethics is character based (Athanassoulis, n.d.) ${ }^{3}$. Campbell's (2008) considers high-stakes testing among many ethical dilemmas that teachers face every day. Her explanation defines virtue ethics (2008) within the context of this study:

Some teachers experience moral qualms about dutifully implementing policies and adhering to expected practices they believe similarly disadvantage or injure students to be related to assessment, discipline, curricula, or school rules. Should a teacher subvert the process of administering standardized tests he or she feels are harmful in ways intended to enhance one's own students' achievement? Some teachers worry that their own responses to classroom situations might result in unintended negative consequences and therefore avoid doing what they might otherwise know they should. (p. 365)

\footnotetext{
3 Thatnassoulis, N. (n.d.). Virtue Ethics. Internet Encyclopedia of Philosophy. Retrieved on October 30, 2014 from http://www.iep.utm.edu/virtue/print

Virtue ethics is a broad term for theories that emphasize the role of character and virtue in moral philosophy rather than either doing one's duty or acting in order to bring about good consequences. A virtue ethicist is likely to give you this kind of moral advice: "Act as a virtuous person would act in your situation."
} 


\section{Macrothink}

Campbell proposes that teachers may manifest virtue ethics when they reflect on their practice and the decisions that they make regarding their students. These decisions can impact the achievement goals of their students. Understanding the consequences of these decisions will also impact the teacher's perception of their actions. Responsibility, accountability, honesty and the valor to admit own weaknesses are what Campbell (2003) believes teachers should manifest in their daily work.

\section{Ethics of Care}

In the ethics of care, Noddings $(1984,2006)$ proposes that the duty of the teacher is to demonstrate a sincere concern for the practice of teaching and the commitment to the learner. The teacher should seek to establish a collaborative teacher-student relationship and maintain a mutual concern for dialogue. The teacher and the student should collaborate to produce an intrinsic desire for learning. Through authentic instruction the student will also gain knowledge in the content area. In the ethic of care, the emphasis is on pedagogical practice and the selection of curriculum. An ethic of care evaluation process would include the evaluation of lesson plans, instructional design and the attainment of the goals and objectives designated in the plan of instruction. The subject matter should be relevant, useful to the student representative of the curriculum content. Also, a caring teacher considers the community where the school is located, so that the culture of the school is reflective of the culture of the community (Noddings, 2005).

\section{Ethic of Justice}

Social justice, fairness and equity in the classroom are the main principles in the ethic of justice. This concept is based on the idea that teachers ought to have integrity in their teaching and a clear sense of what is right and just and, consequently, sometimes, questioning and taking a stand against the status quo (Freire, 1998a, 1998b). Teachers should utilize their best professional judgments to make decisions in the best interest of their students. A fundamental aspect of ethic of justice as Freire proposes is that the teacher should engage in action and reflection (praxis and conscientização) (Freire, 1998a). This action and reflection will result in a democratic classroom that endorses learner centered strategies.

In summary, the ethical teacher framework used in this study describes the teacher as a professional, who integrates the three ethical concepts into their practice. (See Figure 1). Thus, virtue ethics, ethics of care, and ethics of justice overlap and can often be observed in the teacher's practice and instructional activities. 


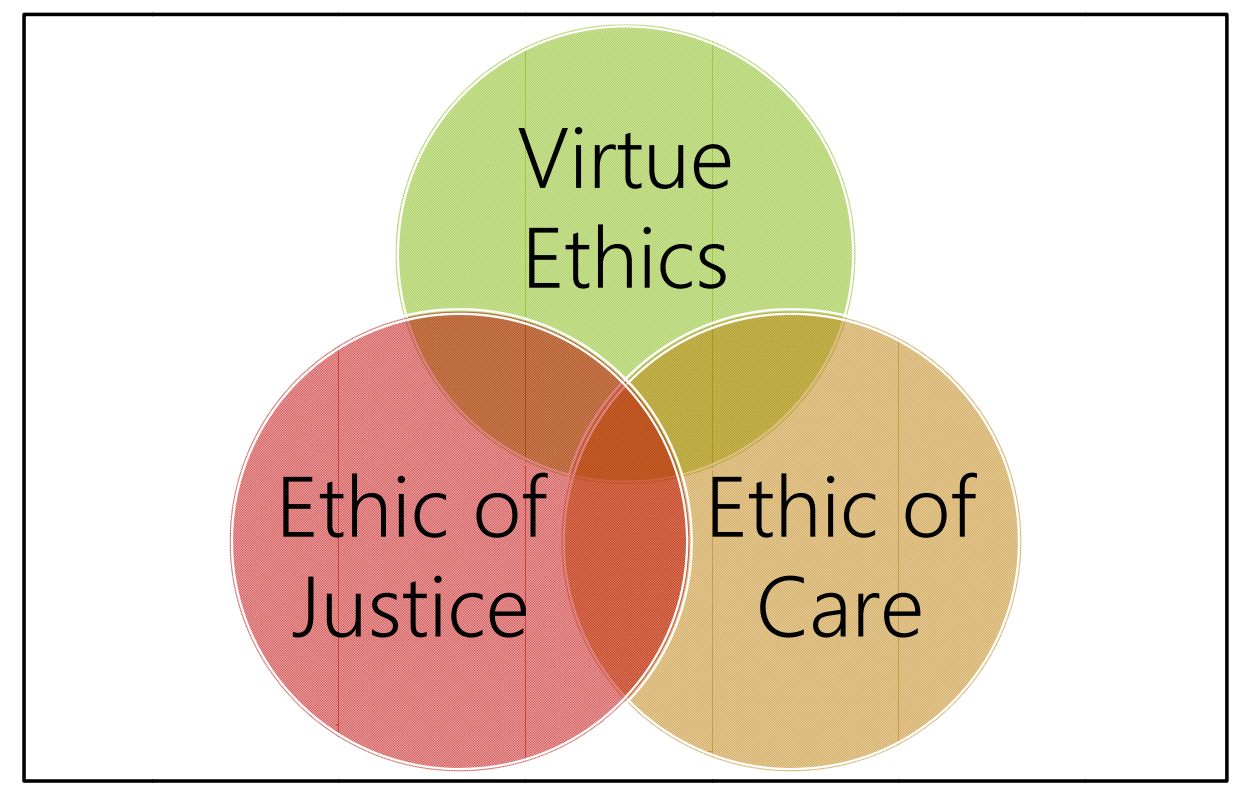

Figure 1. Theoretical Framework Model for the Ethical Teacher

\section{Effects on Teachers on Planning and Delivery of Instruction Method}

This is a qualitative study that followed an inquiry paradigm. The questions were developed to gain information about how teachers perceive the effects of the high stakes testing environment on the delivery of instruction in their classrooms. The relationship between the authentic delivery of the content and the test preparation strategies was explored. In depth interviews were conducted consisting of "a series of three separate interviews with each participant” lasting over 90 minutes following Seidman's (1998) protocol for in-depth interviews.

The interviews were transcribed verbatim and analyzed according to Rossman and Rallis' (2003) framework for data analysis. Elements of trustworthiness were used to maintain credibility, dependability, transferability, conformability and validation by triangulation. To maintain confidentially of the participants, the names, participants and places have been changed. A variety of empirical data resources came from observations, field notes, artifacts, and in-depth interviews. The researcher engaged in discourse with a purposeful set of participants to understand and learn how they experienced certain phenomena.

\section{The Selection of Research Site}

The study was conducted in a small town in a southwestern state. Cotton and grain fields surrounded the community. About $98 \%$ of drivers commute to work approximately 25 miles to the nearest large city of 100, 000 habitants. The nearest urban city is within 245 miles. The town had a total population of approximately $6,121^{4}$ which were represented by $48.5 \%$ Hispanic, $46.2 \%$ Caucasian, $3.2 \%$ African-American and less than $2 \%$ other underrepresented populations. The population living below the poverty level between the years of $2007-2011$ was $27.6 \%$. In addition, $56.3 \%$ of the population was over the age of 16 .

\footnotetext{
${ }^{4}$ http://www.city-data.com/city/
} 
Grade level and subject matter of instruction were determined before selecting the teachers in the study. History and language arts were chosen as the content areas for the study and the eleventh grade as the grade level. The purposeful participants were identified by the principal as successful teachers in their content area. .

\section{Coding of data}

The interviews were transcribed verbatim and analyzed according to Rossman and Ralli's (2003) framework, using a holistic data classification. The researcher manually coded the transcribed interviews and field notes sorting, categorizing, grouping and regrouping the data into chunks of meaningful data. Concept maps were developed for each participant. Each concept map was developed into a topic allowing the comparisons of the conversation to converge as a whole, resulting in the major themes.

\section{Context of the interviews}

The interviews took place during the state mandated standardized test administration. Some subjects had been tested early in the spring, while others were about to take the test. It allowed the researcher an opportunity to observe and interview the participants of the study during and after the assessment.

\section{Participants}

Ms. Adams(pseudonym) is a White female with 19 years of experience teaching English. She teaches five periods of $11^{\text {th }}$ grade English language arts, one writing composition course, and one AP English American Literature class.

Mr. James (pseudonym) is a White history teacher with five years of experience. He teaches one senior English class, one freshman AP Geography class, one junior AP U.S. History class, and four regular junior U.S. History classes.

\section{Findings}

The pressure to increase tests scores and to achieve a reputable accountability rating by the Texas Education Agency (2008) (Exemplary, Recognized, Acceptable, or Low Performing), placed a great burden to many teachers and students ${ }^{5}$ in this school. Anxious, stressed, and pressured is how these teachers perceived the persistent effect of federal, state and local mandates on them (Jones et al., 1999; Madaus \&Russell, 2011; NYSED, 2004; Pedulla, 2003). These feelings were noticeable throughout the interviews and the observations.

The first question to both teachers addressed their perception of federal, state and local mandates and how these influenced their practice. Their responses varied. According to Ms. Adams, the effects of The No Child Left Behind legislation has a greater effect on the administration. She felt that they used the legislation to pressure and evaluate teachers and programs. Both teachers agreed that local administrators were responsible for discussing,

\footnotetext{
${ }^{5}$ Further reading on how the Texas accountability system, standardized, high-stakes test-based accountability system impacts graduation rates for high school students, losing hundreds of thousands youth mostly minority populations see the works of McNeil, Coppola, Radigan \& Vasquez-Heiling (2008). "Avoidable Losses: High-Stakes Accountability and the Dropout Crisis."
} 
interpreting and implementing federal mandates and that the pressure about testing came from local school district administrators and the campus principal the "the gurus of education"(MA1-170). This finding concurred with other studies where administrators interpret and follow mandates and teachers are impacted by their decisions (Herman \& Golan, 1991).

For Ms. Adams, being knowledgeable of the law meant filling out and submitting an application for the distinction of the "Blue Ribbon School Award". She was in charge of the application process for the federal award given to schools that had made notable improvement in students' mathematics and science test scores. Ms. Adams believed that her school would be a recipient of the title as test scores in the previous year showed positive results, particularly for minority children. On the other hand, Mr. James perceived the federal government as being too involved in the personal lives of the teachers, "I came from a district meeting this morning and my understanding is that the federal government is going to be more involved... as far as auditing... they will be in our business all the time in the future" (MJ1-1174). Also he believed that the federal government should take their "hands off of education" and graduation rates should not be attached to funding "because as soon as you attach federal money to how many students graduate, I guarantee more students are going to graduate, even if they don't deserve it (MJ1-144).He also explained that because schools are afraid to lose funds and grade level promotion and graduation rates have increased, regardless as to whether or not - or the degree to which -students' educational experiences reflect such improvement. This finding concurs with the effects of high stakes testing studied by Stecher, (2000) where he found that administrators enacted policies to increase test scores at the expense of student knowledge. He insisted that students were not reaching a high academic level nor were they sufficiently prepared to go to college.

For a high-stakes testing era for teaching, obviously stress is on myself, stress is on my students... As far as the school goes, it is very stressful, and especially this time of the year because the test is next week. So we are reviewing like crazy. (Mr. James 1-L1574)

Ms. Adams explained how she felt about the pressure,

"You can feel yourself feeling the pressure and clenching your jaw and snapping at people maybe a little more, 'Oh we haven't covered this, covered that, we are not right where we need to be, we are not looking as good as we need to,' and so yes, you can feel that [pressure.“

Both teachers planned their instruction around the standards to be tested. The content of the test was the driving force behind the instruction in the classroom. Ms. Adams seemed to succumb to the pressure and teach to the test.

I think it is unfortunate when teachers are too driven by that one test result. I think it limits sometimes the way we interact with kids and what we bring to them if are too focused on it. I understand the importance of it; I allow it to drive a lot of what I do curriculum-wise (Ms. Adams). 
In contrast, Mr. James acknowledged that the lessons delivered to the student's emphasized content specifically related to the test. He explained, "If I am not reviewing for the TAKS, my lesson is $90-95 \%$ TAKS material . . . until the TAKS test ends; then we relax, and do other things that are not related to TAKS at all. "(MJ1-351)

Consistent with other studies, the scope and content of the curriculum was dictated by the test (Crocco \& Costigan, 2007) resulting in a narrowed curriculum.

The limited time to cover the curriculum content was of specific concern to Ms. Adams. The performance expectations of her students on the assessment seemed to infringe on that priority. She indicated that some standards related to integrating literature and historical contexts were neglected because of the assessment expectations. (TEKS 11E, MAart-8). For example, tracing the history of literature in America, its movements, and important authors.

Not that we don't do literature, we do less of it, we don't cover . . the Native American and then you continue with the Europeans . . .all part of American history... as far to really getting to trace it, and its development of movements, and how it fits historically, I had to let go of that notion!

Ms. Adams indicated that when she did attempt to address the historical contexts, she covered the content "only slightly." "I will mention it or say it or try to give them a little sweep".

[Students] write an essay discussing how a person can change your life for the better, write an essay discussing how your beliefs systems affects your choices, these are the type of questions that they ask them on that one essay question, and they are kind of philosophical sounding and so what we work on is just making sure that we get very personal, very specific, very creative,

I am not going to be able to teach this book and it should be taught. I am grading research papers, it needs to be taught, we can do such great lessons, but it is not going to happen, so now the question is because you are not doing it the way you should or the way you really could with this book are you just going to let it go? Or are you going to ask them to read it at least?

On the other hand, Mr. James did not perceive that the assessment had narrowed his curriculum. He indicated that he added more to his curriculum because of the test:"I add stuff to my material, to make it more, to make it more TAKS oriented. Some things I did not think were important the state did, so I went back and included those."

In addition, he indicated that he covered everything that was included on the state standards.

It is up to the teacher if you allow it to get dumbed down, then it will, and I think, I have the kids telling me that half of the stuff we studied wasn't on there [the test], that is a sign maybe I went above and beyond . . .so it is up to the teacher. The teachers devoted considerable class time discussing the test and preparing for the assessment. James and Ms. Adams explained:

Everyday! It's part of my review, the stuff I review is TAKS information . . my main subject would consist of 5 minutes of TAKS review, 5 to 10 minutes of previous chapters (just oral 
questions) review ... . That is part of my 10-15 minutes at the beginning; there is TAKS vocabulary ... I am reviewing them to see what they remember, but ultimately is for the TAKS test at the end of the year (Mr. James)

I do talk about the test, and I will say, we are getting ready for it, and I just justify why we are doing a particular lesson. We are working on these objectives, this is how it is tested, this is how it looks, you will see it as maybe five different ways this particular objective; here is an example, here is [another] example, so we'll look at it and will talk about it (Ms. Adams)

Ms. Adams explained that although a teacher cannot know the specific content of the state test, he or she can become very familiar with the type of questions in each of the various objectives.

You will see that every time, you just don't know what is going to be [on the test], but [it] always [will] be fiction, nonfiction, and a visual, and there will be like 28 multiple-choice questions over that portion. Over those, three reading selections. They are three open-ended questions that have eight lines and maybe eleven lines where students respond ... They always have to show evidence from the text on these responses".

Ms. Adams also disclosed that she used the test as a tool for teaching text analysis. She gave details:

Another thing that I have done more over the last few years is ... I've written "prompts" .. . very similar to TAKS like questions that every individual person in each class do; so they get up and present it and everybody is listening for those things we talked about, and the kids score them ... so they are hearing prompt responses and scoring using rubrics ... to at least 60 prompts.

On the other hand, Mr. James believed that repetition of questions, memorization of dates and factual knowledge were the most effective practices for multiple-choice test preparation. Mr. James utilizes practice games and exams to enhance his instruction.

"For the TAKS test, I got Jeopardy games from these workshops . . . I do note cards, find a partner with a matching note card, that is what we are doing today and in the next period."

These strategies are utilized throughout the year to monitor both what he has taught and what students have learned. He explained:

[The] practice exams, I do [them] in every class whether before the TAKS test or the AP test or the freshman TAKS test, whatever, hum, just to see, like I said what areas we need to review more than areas they may have mastered already, the areas they are lacking .

In general, both teachers found that the use of visual aids, games, and/or rubrics helped students to engage in the lesson, learn the subject matter and prepare them for the test.

\section{After the Test}

After the TASK test, both teachers engaged the students in activities that were not directly related to the assessment. 
I do a Billy Joel project. He has a song "We Didn't Start the Fire" . . I had a teacher who did this with me in high school . . . I do it with them [my students]. They enjoy the song, they write the next verse for their lifetime, things that fit his (Billy Joel) style of the song...that is the big project I do after TAKS test that they seem to enjoy and has nothing to do with [with the TAKS], and it is a fun project, to write a song.

I do a lot more video clips of events that have happened in their [students] lifetime, and I only have to get to 1972, I said 1975 with the Vietnam withdrawal . . so, I don't make them take notes anymore, after the TAKS test, just do video clips and things that happened from the time they were born up until now, and they seem to enjoy that, and like I said, it has nothing to do with TAKS whatsoever.

Ms. Adams allowed her students read their novel and work on their research paper. This gave her the opportunity to work on her grades and catch up on her other teaching responsibilities.

\section{The Conclusion}

The ethical teacher understands the unique responsibilities of the profession. They are cognizant of the specific needs of their students. They understand learning theory and utilize instructional strategies that enhance their ability to maximize instruction in the classroom. This knowledge and expertise and the desire to do what is best for the students is the basis for the ethical teacher framework.

As noted during observations and interviews, theses teachers showed a genuine concern for their students. They were concerned with student performance on the mandated assessments but they also understood that content area instruction was important. Students failing to pass the $11^{\text {th }}$ grade mandated tests is a greater predictor for dropping out of high school (Clark, Haney, Madaus, 2000; McNeil, et al., 2008).Ms. Adams ethical knowledge empathized the need to reach all her students as she was cognizant of their abilities and knowledge. She stated:

I've got to make sure I am reaching the lowest students; there is some good on that really . . . you have to reach your lowest students or your most challenged student, is one of the things that ensures the teachers are attempting to reach out and if we don't have this kind of standards [the tested standards], how do we know?

From the perspective of the ethical teacher, Campbell (2006) suggests that teachers make decisions that will focus on the wellbeing of their students. The teachers in the study complied with the requirements of their job descriptions and attempted to meet the curriculum requirements of their content areas. But as Campbell noted, both teachers were engaged in implementing test preparation strategies for their students as they prepared for the assessment. Teachers may engage in what they are told to do [emphasis added] without being fully aware of their moral and ethical implications of their actions and decisions (2006).

The ethic of care was evident as both teachers were concerned for the wellbeing of their students. They wanted their students to be successful on the mandated assessment and within the curriculum content. The teachers in the study utilized instructional strategies that they felt 
would maximize the opportunity for the students to succeed on both the mandated assessment and the academic content of the course. The ethic of care was evident in my discussions with the teachers during the observations and subsequent conversations. The teachers in the study demonstrated the ethic of care concept by tutoring before and after school. The teachers connected with the students on a daily basis in an effort to maximize the opportunities for the students to be successful. The teachers created alternative instructional strategies to reinforce the academic content within the course and on the assessment. As Noddings noted, these teachers demonstrated a sincere concern for the practice of teaching and a commitment to the learner.

The teachers demonstrated an ethic of justice throughout the course of the study. Each teacher demonstrated a professional approach toward instruction. Each teacher expressed an understanding of the priorities related to implementing a quality instructional plan. They also realized the importance of the assessment and their responsibility to provide the students with the maximum opportunity to be successful on the test. The teachers expressed a general approval of the standardized assessments and they indicated no overt opposition to testing the students. During the observations the teachers were observed addressing the expected goals and objectives of the curriculum. As Freire indicated in his study these teachers used their best professional judgments to make decisions in the best interest of their students.

Mr. Jackson explained that the state-mandated test, the TAKS, gives both-him and his students - a goal to reach at the end of the year: "A lot of teachers have problems with the TAKS test, I don't.". . . I think you have to have some level, some bar to reach, and some level that the students need to get into." In a similar fashion, Ms. Adams also believed the state test expectations helped teachers reach all students and that those expectations enhanced their role as ethical teachers. She felt that the teacher's obligation with respect to the assessments would assist teachers in meeting the needs of all students. The ethic of justice was apparent as both teachers were critical of the minimum skills expectation concept on the assessment. They felt that the assessment limited the expectations of the student and encouraged mediocrity.

Is a minimum skills test, and the test only measures minimum skills focusing mainly on grammar, proofreading - a reading comprehension of three passages: fiction, nonfiction, and a visual - cartoon or advertisement, each with open-ended questions requiring no more than a paragraph to respond-(Ms. Adams)

"It is] a very factual multiple-choice ... who did this, what year did this happen, when did this happen, and there is not too many whys in the multiple-choice [test].”(Mr. James)

From the perspective of the ethic of justice, Freire (1985) would call this practice banking education style of teaching where the student is "a passive being [and] the object of the process of learning to read and write, and not its subject... having so little, if anything, to do with the student's socio cultural reality" (p. 46).Both teachers agreed that the test focused on basic knowledge and basic skills. 
During the professional career of a teacher, many individuals find it difficult to make pedagogical decisions about what they need to teach and how they need to teach it. They also are expected to meet the academic, social and psychological needs of their students. With the additional mandated assessment expectations of the schools and districts on the teacher, an already ethical dilemma is exasperated. The high-stakes test becomes the facto way to teach, assess and evaluate teacher instruction. The effectiveness of a school, the district, and the students is evaluated through the assessments.

The information gathered in this study cannot be applied to all teachers. As I left the observations and completed and analyzed the interviews, I realized that the teachers in this study would do whatever they thought was necessary to facilitate the success of their students. In both cases, helping the students graduate and facilitating their vision for a future was more important than teaching to the test. However, the test, was a main factor in the academic future of these students. The teachers appeared to be struggling with the consequences of failure. Stress and concern were obvious obstacles that the teachers and the students encountered during the observation period.

The teachers showed a genuine interest in their students. They provided the students with a caring atmosphere in the school which transcended into the personal lives of the students. They were connected with their students and their community. The relationships with students and the love for teaching was evident in the way they interacted and talked about their subject matter and the students. Teaching values and beliefs in best practice were a priority for the teachers. Teaching to the test was not an option. The teachers used the test to engage the students in reflective analysis of the tests construction. The emphasis was not on the passing or failing of the test, however, the conflicts of their values and beliefs with respect to the test did cause the teachers to struggle with frustration.

Placing a value on students graduating and ensuring their advancement after high school was more important to these teachers than teaching to the test. Learning to answer the questions and to look at the test in a critical way was important. Implementing creative ways to combine state standards, state requirements, content and learning abilities was also critical. The creativity of these teachers to plan instruction around the standards and make students aware of what was expected of them from the test was also important. Feeling autonomous in their practice and in the collection of material that was appealing to the students was paramount. Providing the students with opportunities for engagement and authentic opportunities to learn and remain on task was a priority.

The study revealed that even though a few individuals will leave the profession as a way to show their disagreement with the implementation of the policies and the increased assessments, others will comply with the norms and mandates dictated by the State and the District and will make educated ethical decisions based on their perceived responsibilities and knowledge of their ethical values. Even though the compliance with mandated academic strategies may not always be in the best interest of the student, the ethical teacher will make educated decisions based on their value system. If their value system includes a healthy 
perception of the ethics concepts, teachers will make educated decisions based on knowledge and what is best for the student.

\section{References}

Abrams, L. (2004, February). Teachers' views on high-stakes testing: Implications for the classroom. Policy Brief. Education Policy Research Unit. Retrieved on May 28, 2005, from http://edpolicylab.org

Abrams, L., \& Madaus, G. (2003, November). The lessons of high-stakes testing. Educational Leadership, 6(3), 31-35.

Abrams, L., Pedulla, J., \& Madaus, G. (2003). Views from the classroom: Teachers' opinions of statewide testing programs. Theory into Practice, 42(1), 18-29. http://dx.doi.org/10.1207/s15430421tip4201_4

Au, W. (2011). Teaching under the new Taylorism: high-stakes testing and the standardization of the 21st century curriculum. Journal of Curriculum Studies, 43(1), 25-45. http://dx.doi.org/10.1080/00220272.2010.521261

$\mathrm{Au}, \mathrm{W}$. (2007). High-stakes testing and curricular control: a qualitative metasynthesis. Educational Researcher, 36(5), 258-267. http://dx.doi.org/10.3102/0013189X07306523

Beck, F. D., \& Shoffstall, G. W. (2005). How do rural schools fare under a high-stakes testing regimen? Journal of Research in Rural Education, 20(14), 1-14.

Booher-Jennings, J. (2005). Below the bubble: "Educational triage" and the Texas accountability system. American Educational Research Journal, 42(2), 231-268. http://dx.doi.org/10.3102/00028312042002231

Burroughs, S., Groce, E., \& Webeck, M. L. (2005). The social studies in the age of testing and accountability. Educational Measurement: Issues \& Practice, 24(3), 3-20 http://dx.doi.org/10.1111/j.1745-3992.2005.00015.x

Campbell, E. (2003). The ethical teacher. Philadelphia, PA: McGraw-Hill Education. Campbell, E. (2008).

Campbell, E. (2008). The ethics of teaching as a moral profession. Curriculum Inquiry, 38(4), 357-385. http://dx.doi.org/10.1111/j.1467-873X.2008.00414.x

Carnoy, M., Elmore, R., \& Siskin, L. S. (2003). The new accountability: High schools and high-stakes testing. New York: Routledge.

Cimbricz, S. (2002). State-mandated testing and educators' beliefs and practice. Educational Policy Analysis Archives, 10(2). http://dx.doi.org/10.14507/epaa.v10n2.2002

Cochran-Smith, M., \& Lytle, S. (2006). Troubling images of teaching in No Child Left Behind. Harvard Educational Review, 76(4), 668-697. http://dx.doi.org/10.17763/haer.76.4.56v8881368215714 
Craig, C. J. (2004). The dragon in the school backyard: The influence of mandated testing on school context and educators' narrative knowing. Teachers College Record, 106(6), 1229-1257. http://dx.doi.org/10.1111/j.1467-9620.2004.00378.x

Craig, R. (2008). Are public schools successful? In F. Schultz (Ed.), Education (pp. 124-125). Boston, MA: McGraw-Hill.

Crocco, M. S., \& Costigan, A. T. (2007). The narrowing of curriculum and pedagogy in the age of accountability: Urban educators speak out. Urban Education, 42 (6), 512-535. http://dx.doi.org/10.1177/0042085907304964

Cross, C. T. (2004). Political education: National policy come to edge. New York, NY: Teachers College Press.

Darling-Hammond, L (2003). Standards and assessments: Where we are and what we need. Teachers College Record, 111(1). Retrieved January 14, 2008, from http://www.tcrecord.org/ID=14689

Freire, P. (1998a). Teachers as cultural workers: Letters to those who dare to teach. Boulder, CO: Westview Press.

Freire, P. (1998b, 2004). Pedagogy of the oppressed. New York: The Continuum International Publishing Group.

Freire, P. (2001). Pedagogy of freedom: Ethics, democracy, and civic courage. (pp. 1-21). Lanham, MD: Rowman \& Littlefield.

Gordon, B., \& Reese, M. (1997). High-stakes testing: Worth the price? Journal of School Leadership, 7(July), 345-368.

Grant, S. G. (2001). An uncertain lever: Exploring the influence of state-level testing in New York State on teaching social studies. Teachers College Record, 103(3), 398-426. http://dx.doi.org/10.1111/0161-4681.00120

Hampton, E. (2005). Standardized or sterilized? Differing perspectives on the effects of high-stakes testing in West Texas. In A. Valenzuela (Ed.), Leaving children behind: How "Texas-style" accountability system fails Latino youth (pp. 179-200). New York: State University of New York Press.

Haney, W. (2000). The Texas miracle in education, 8(41). Retrieved June 5, 2006, from http://epaa.asu.edu/epaa/v8n41

Herman, J., \& Golan, S. (1991). Effects of standardized testing on teachers and learning-Another look. (CSE Tech Rep. 334). Los Angeles: National Center for Research on Evaluation, Standards, and Student Testing. University of California at Los Angeles.

Hinde, E. R. (2003). The tyranny of the test: Elementary teachers' conceptualizations of the effects of state standards and mandated tests on their practice. Current Issues in Education [Online], 6(10). Retrieved on May 5, 2007 from, http://cie.asu/volume6/ number10/index.html 
Hoffman, J. V., Assaf, L. C., \& Paris, S. G. (2001). High-stakes testing in reading: Today in Texas, tomorrow? The Reading Teacher, 54(5), 482-492.

Kozol, J. (2005). The shame of the nation: The restoration of apartheid schooling in America. New York: Crown Publishers.

Madaus, G. (1988). The distortion of teaching and testing: High-stakes testing and instruction. Peabody Journal of Education, 65(3), 29-46. http://dx.doi.org/10.1080/01619568809538611

Madaus, G., \& Russell, M. (2011). Paradoxes of High-Stakes Testing. Journal of Education, 190(1/2), 21-30.

McNeil, L. M. (2005). Faking equity: High-stakes testing and the education of Latino youth. In A. Valenzuela (Ed.), Leaving children behind: How "Texas-style" accountability system fails Latino youth (pp. 57-112). Albany, NY: State University of New York Press.

McNeil, L. M., Coppola, E. Radigan, J., \& Vasquez Heilig, J. (2008). Avoidable losses: High-stakes accountability and the dropout crisis. Education Policy Analysis Archives, 16(3). Retrieved on February 10, 2010 from http://epaa.asu.edy/epaa/v16n3/.

McNeil, L. M., \& Valenzuela, A. (2001). The harmful effects of the TAAS system of testing in Texas: Beneath the Accountability Rhetoric. In G. Orfield \& M. Kornhaber (Eds.), Raising standards or raising barriers? Inequality and high-stakes testing in public schooling (pp.127-150). New York: Century Press.

Menken, K. (2006). Teaching to the test: How No Child Left Behind impacts language policy, curriculum, and instruction for English language learners. Bilingual Research Journal, 30(2), 521-546. http://dx.doi.org/10.1080/15235882.2006.10162888

Murillo, E., \& Flores, S. (2002) Reform by shame: Managing the stigma of labels in high-stakes testing. Educational Foundations, 4 (spring), Retrieved on September 21, 2005 from http://www.findarticles.com/p/articles/mi_qa3971/is_200204/ai_n9069151

Nasser, H. E., \& Overberg, P. (8/10/2011). Census tracks 20 years of sweeping change. USA Today. Retrieved on Nov.11, 2014 from http://usatoday30.usatoday.com/news/nation/census/2011-08-10-census-20-years-change_n.h tm

Noddings, N. (1984). Caring: A feminine approach to ethics and moral education. Berkley, University of California Press.

Noddings, N. (2005). Educating citizens for global awareness. New York: Educators College, Columbia University.

Noddings, N. (2006). Critical lessons: What our schools should teach. New York: Cambridge University Press. http://dx.doi.org/10.1017/CBO9780511804625

Pedulla, J., Abrams, L. M., Madaus, G., Russell, M., Ramos, M., \& Miao, J. (2003). Perceived effects of state- mandated testing programs on teaching and learning: Findings 
from a national survey of teachers. Chestnut Hill, MA: National Board on Educational Testing and Public Policy.

Rossman, G. B., \& Rallis, S. F. (2003). Learning in the field: An introduction to qualitative research. Los Angeles: CA, SAGE.

Santoro, D. (2011). Good teaching in difficult times: Demoralization in the pursuit of good work. American Journal of Education, 118 (Nov), 1-23. http://dx.doi.org/10.1086/662010

Siskin, L. (2003). Outside the core: Accountability in tested and untested subjects. In M. Carnoy, R. Elmore, \& L. S. Siskin (Eds.), The new accountability: High schools and high-stakes testing (pp. 87-98). New York: RoutledgeFalmer.

Sloan, K. (2005). Playing to the logic of the Texas accountability system: How focusing on "ratings"—not children - undermines quality and equity. In A. Valenzuela (Ed.), Leaving children behind: How "Texas-style" accountability system fails Latino youth (pp. 153-178). Albany, NY: State University of New York Press.

Stecher, b. (2002). Consequences of large-scale, high stakes testing on school and classroom practice. In L. S. Hamilton, B. M. stecher, \& S. P. Klein (Eds.), Making sense of test-based accountability in education. (pp. 79-100). Santa Monica, CA: RAND.

Sunderman, G. L., Tracey, C. A., Kim, J., \& Orfield, G. (2004). Listening to teachers: Classroom realities and No Child Left Behind. Cambridge, MA: The Civil Rights Project at Harvard University.

Texas Education Agency (2008). Accountability Manual. Retrieved July 12, 2008, from http://ritter.tea.state.tx.us/perfreport/account/2008/manual/index.html

U.S. Department of Education. (2010). Building on results: A blueprint for strengthening the No Child Left Behind Act. Washington, D. C: Author.

Valencia, R., \& Villarreal, B. (2005). Texas' second wave of high-stakes testing: Anti-social promoting, legislation, grade retention, and adverse impact on minorities. In A. Valenzuela, Leaving children behind: How "Texas-style" accountability fails Latino Youth. (pp. pp.113-152). New York: State University of New York Press.

Valenzuela, A. (2005). Leaving children behind: How "Texas-style" Accountability system fails Latino youth. Albany, NY: State University of New York Press.

Vasquez-Heiling, J. \& Darling-Hammond, L. (2008). Accountability Texas-Style: The Progress and Learning of Urban Minority Students in a High-Stakes Testing accountability. Educational Evaluation and Policy Analysis, 30(2), 75-110. http://eepa.aera.net http://dx.doi.org/10.3102/0162373708317689

Watanabe, M. (2007). Displaced teacher and state priorities in a high-stakes accountability context. Educational Policy, 21(2), 311-368. http://dx.doi.org/10.1177/0895904805284114

Waters, B. (November 13, 2014). Tyler ISD scores low in meeting the needs of special groups of students. Tyler Morning Telegraph. E-edition. Retrieved on Nov, 13, 2014 from 
http://www.tylerpaper.com/TP-News+Local/208673/tyler-isd-scores-low-in-meeting-the-nee ds-of-special-groups-of-students\#.VGV1nFfF-DQ

Wills, J. (2007). Putting the squeeze on social studies: Managing teaching dilemmas in subject areas excluded from state testing. Teachers College Record [Online], 109(8). Retrieved on May 20, 2007, from http://www.tcrecord.org ID Number: 14080

Yeh, S. S. (2005). Limiting the unintended consequences of high-stakes testing. Educational Policy Analysis Archives, 13(43), 1-19. http://dx.doi.org/10.14507/epaa.v13n43.2005 